\title{
Facile Preparation of Novel Manganese Dioxide Modified Nanofiber and Its Uranium Adsorption Performance
}

\author{
Wuqing Tao1,2, Riwen $\mathrm{Lv}^{2}$, Qinqin Tao ${ }^{2 *}$ \\ ${ }^{1}$ Department of Radiochemisty, China Institute of Atomic Energy, Beijing, China \\ ${ }^{2}$ State Key Laboratory of Nuclear Resources and Environment, East China University of Technology, Nanchang, China \\ Email: *taoqinqin@ecut.edu.cn
}

How to cite this paper: Tao, W.Q., Lv, R.W. and Tao, Q.Q. (2021) Facile Preparation of Novel Manganese Dioxide Modified Nanofiber and Its Uranium Adsorption Performance. Journal of Applied Mathematics and Physics, 9, 1837-1852.

https://doi.org/10.4236/jamp.2021.97118

Received: May 11, 2021

Accepted: July 27, 2021

Published: July 30, 2021

\begin{abstract}
In this study a novel manganese dioxide modified nanofiber was facile prepared using the electrospinning technique. The as-prepared manganese dioxide/poly(vinyl alcohol)/poly (acrylic acid) (briefly as $\mathrm{MnO}_{2}$-PVA/PAA) was firstly characterized by SEM, FT-IR, XRD, stress-strain test and secondly tested as an adsorbent to remove uranium from aqueous solution. Effect of $\mathrm{pH}$, ionic strength, initial uranium concentration, mixing time, temperature on the adsorption, reusability and adsorption mechanism were illustrated. The theoretical adsorption amount of $\mathrm{MnO}_{2}$-PVA/PAA calculated as 398.85 $\mathrm{mg} / \mathrm{g}$ was competitive compared with the reported values. The study proved $\mathrm{MnO}_{2}-\mathrm{PVA} / \mathrm{PAA}$ is promising in the uranium removal from aqueous medium.
\end{abstract}

\section{Keywords}

Uranium, Manganese Dioxide, Nanofiber, Electrospin

\section{Introduction}

Global fossil fuels such as coal, petroleum and natural gas are being intensively consumed and expectedly depleted within two hundred years in terms of currently annual consumption [1]. Nuclear energy is an extremely important candidate owning to high energy density $\left(3.9 \times 10^{6} \mathrm{MJ} / \mathrm{Kg}\right.$ uranium) [2] and zero greenhouse gas emissions [3]. Nevertheless, there is a tricky problem associating with nuclear energy. Uranium is an element of non-degradable nature, strong fluidity and long-lasting pollution of chemical and biological toxicity. By aqueous organisms uranium can migrate with the food chain readily, finally into 
human body. Once over the limited range many fatal and irreversible injuries occur in lungs, kidneys or other organisms. The World Health Organization prescribes uranium limit as $14.4 \mu \mathrm{g} / \mathrm{L}$ [4]. Overall remediation of waters contaminated by uranium is of great significance.

At present many remediation approaches includes chemical precipitation [5], solvent extraction [6], ion exchange [7], particle flotation [8], membrane separation [9], catalytic [10] and adsorption [11] [12], in which the adsorption attains more attention due to high feasibility, low energy cost and less second waste. Besides adsorption craft parameters the adsorbent plays a key role.

Metal oxide is explored as an effective kind of adsorbent for waste water remedy. Manganese dioxide $\left(\mathrm{MnO}_{2}\right)$ presents excellent potentiality in this respect owing to acidity stability, negatively charged surface, low cost and high affinity [13]. The challenges in utilization of manganese dioxide as an adsorbent are as following: 1) Uranium uptakes of the raw manganese dioxide were demonstrated as commonly less than $60 \mathrm{mg} / \mathrm{g}$ [14]; 2) The fine particle size and aggregation of manganese dioxide lead to the difficulty in solid-liquid separation as well as the low efficiency in removal of uranium. It is such reason that many modification of manganese dioxide were conducted. For example, Zhu et al. [15] used poly(N-hydroxymethylacrylamide/2-hydroxyethylacrylate)hydrogel immobilized manganese dioxide for removal of $\mathrm{Pb}^{2+}, \mathrm{Cu}^{2+}, \mathrm{Cd}^{2+}$ and $\mathrm{Ni}^{2+}$. Kim et al. [16] fabricated magnetic manganese dioxide nanocomposites $\left(\mathrm{Fe}_{3} \mathrm{O}_{4} / \mathrm{MnO}_{2}\right)$, which could be recovered by an external magnet.

Electrospinning is one of the most compatible techniques to produce continuous nanofibers of inorganic, organic, metals and composites [17]. The as-produced nanofibers often with large specific surface area and abundant porosity are promising in the fields of catalysis [18], batteries [19], medicine [20] and separation [21] [22]. To separate metal ions many electrospinning nanofibers were reported, for example, polyacrylonitrile/ $\mathrm{SiO}_{2}$ for $\mathrm{Th}^{4+}, \mathrm{U}^{6+}, \mathrm{Cd}^{2+}$ and $\mathrm{Ni}^{2+}$ [23], polyvinylpyrrolidone/ $\mathrm{CeO}_{2} /(3$-mercaptopropyl)trimethoxysilane for $\mathrm{Pb}^{2+}$ and $\mathrm{Cu}^{2+}$ [24], poly(vinyl alcohol)/tetraethoxysilane/(3-aminopropyl) triethoxysilane for $\mathrm{Cd}^{2+}$ [25], poly(vinyl alcohol)/titanium oxide/zinc oxide for $\mathrm{Th}^{4+}$ [26], polyvinylpyrrolidone/iron acetylacetonate for $\mathrm{Hg}^{2+}$ [27], poly(vinyl alcohol)/titanium oxide for $\mathrm{Th}^{4+}$ and uranyl [28], chitosan/multi-walled carbon nanotubes for $\mathrm{Cr}^{6+}$ [29], chitosan/hydroxyapatite for $\mathrm{Pb}^{2+}, \mathrm{Co}^{2+}$ and $\mathrm{Ni}^{2+}$ [30].

In the study of $\mathrm{MnO}_{2}$-PVA/PAA nanofiber was prepared by electrospinning and further in-situ coating. Advantages of the consequent $\mathrm{MnO}_{2}-\mathrm{PVA} / \mathrm{PAA}$ are as following: 1) high availability; 2) better uranium separation performance including high uranium uptake capacity, reusability and mechanical strength. $\mathrm{MnO}_{2}$-PVA/PAA was tested for uranium separation effectivity at different $\mathrm{pH}$, ionic strength, adsorption time, initial uranium concentration and temperature. The kinetics, isotherms, thermodynamics, reusability and membrane performance were discussed. The results herein demonstrated the high potential of $\mathrm{MnO}_{2}-\mathrm{PVA} / \mathrm{PAA}$ as a candidate in membrane separation for uranium. 


\section{Experimental Section}

\subsection{Materials and Instruments}

All chemicals of reagent-grade purity were attained from commercial companies and directly utilized as received. The surface morphology of electrospinning nanofiber was measured by SEM (Nova Nano 450, Netherlands FEI Company). Chemical groups in nanofiber were observed by FT-IR (Nicolet 380, Thermo Nicolet Corporation). The crystal structure was determined by XRD (D8. Advance, Shuyun instruments (Shanghai) Co., Ltd). XPS measurement was performed with Escalab $250 \mathrm{Xi}$ (Thermo Fisher). The hydrophily was analyzed by measuring contact angle (JC2000C1, Shanghai Zhongchen Digital Co., Ltd.). The mechanical property was measured using Universal mechanical testing machine (WDT-5, Shenzhen Kaiqiangli Experimental Instrument Company).

\subsection{Preparation of PVA/PAA and $\mathrm{MnO}_{2}$-PVA/PAA Nanofiber}

The solution composed of $1.6 \mathrm{~g}$ poly (vinyl alcohol) and $10 \mathrm{~mL}$ deionized water was magnetically stirred to homogeneous phase at $85^{\circ} \mathrm{C}$, followed by addition of $0.3 \mathrm{~g}$ poly (acrylic acid). After cooling down to room temperature the resultant solution stirred for well-mix was stored as the electrospinning precursor solution.

The electrospinning operation for PVA/PAA nanofiber was described as the following. The above precursor solution was transferred in a syringe equipped with a stainless-steel needle of $22 \mathrm{G}$ that serving as the anode. A rotation drum connected with the cathode was used as a collector. The anode-cathode voltage and distance were set as $23.5 \mathrm{kV}$ and $15 \mathrm{~cm}$, respectively. The flow rate was fixed as $0.5 \mathrm{~mL} / \mathrm{h}$. The collected nanofiber was thermo-treated for $3 \mathrm{~h}$ for cross-linking esterification reaction between PVA and PAA. The final mat was poly(vinyl alcohol)/poly(acrylic acid) nanofiber briefly as PVA/PAA.

In-situ coating of $\mathrm{MnO}_{2}$ onto PVA/PAA was completed via a redox chemical reaction. Specifically, the mixture containing $1.0 \mathrm{~g}$ PVA/PAA and $100 \mathrm{~mL}$ potassium permanganate solution $(2.0 \mathrm{~g} / \mathrm{L})$ was agitated for $2 \mathrm{~h}$ at $35^{\circ} \mathrm{C}$ at $\mathrm{pH}=2.0$, followed by dropwise addition of $5.0 \mathrm{~mL}$ absolute ethanol. The resultant solution was continuously agitated for $30 \mathrm{~min}$ until clarification. The nanofiber was taken out from the solution, washed with deionized water for three times, and dried at $85^{\circ} \mathrm{C}$ for $5 \mathrm{~h}$. The as-prepared product was named as $\mathrm{MnO}_{2}-\mathrm{PVA} / \mathrm{PAA}$ nanofiber.

\subsection{Uranium Adsorption Performance Test}

All batchwise experiments were conducted by controlling $\mathrm{MnO}_{2}$-PVA/PAA mass as $10 \mathrm{mg}$ and solution volume as $50 \mathrm{~mL}$. The solution $\mathrm{pH}$ was kept at 6.0 except the study on $\mathrm{pH}$ influence where $\mathrm{pH}$ was from 2.5 to 6.0 with interval value of 0.5 . The $\mathrm{NaClO}_{4}$ concentration was zero except the study on effect of ionic strength, in which $\mathrm{NaClO}_{4}$ concentration ranged from $0.1 \mathrm{~mol} / \mathrm{L}$ to 0.6 $\mathrm{mol} / \mathrm{L}$. The uranium concentration in feed solution was fixed at $50 \mathrm{mg} / \mathrm{L}$ except 
the isotherms study. The duration was set as $2 \mathrm{~h}$ except the kinetics research where it varied from $5 \mathrm{~min}$ to $150 \mathrm{~min}$. The environmental temperature was controlled at $298.15 \mathrm{~K}$ except in thermodynamics experiment, in which it was in the range of $288.15 \mathrm{~K}$ to $318.15 \mathrm{~K}$ with an interval of $5 \mathrm{~K}$. After adsorption, the nanofiber was taken out and the residue uranium concentration in solution was detected with the standard arsenazo III method. The uranium uptake amount ( $q_{\mathrm{e}}$ $(\mathrm{mg} / \mathrm{g}))$ was calculated out using Equation (1):

$$
q_{e}=\frac{\left(\left[\mathrm{UO}_{2}^{2+}\right]_{0}-\left[\mathrm{UO}_{2}^{2+}\right]_{e}\right) V}{m}
$$

where $\left[\mathrm{UO}_{2}{ }^{2+}\right]_{0}$ is uranium concentration in the feed solution $(\mathrm{mg} / \mathrm{L}) ;\left[\mathrm{UO}_{2}{ }^{2+}\right]_{\mathrm{e}}$ is uranium concentration $(\mathrm{mg} / \mathrm{L})$ before solid-liquid separation; $V(\mathrm{~L})$ is the volume of uranium-containing feed solution; $m(\mathrm{~g})$ is the mass of $\mathrm{MnO}_{2}-\mathrm{PVA} / \mathrm{PAA}$ or PVA/PAA.

The strip experiment followed the adsorption experiment were carried out by washing the spent nanofiber with eluate solution $(50 \mathrm{~mL}, 1.0 \mathrm{~mol} / \mathrm{L})$ such as $\mathrm{HCl}, \mathrm{H}_{2} \mathrm{SO}_{4}, \mathrm{HNO}_{3}, \mathrm{Na}_{2} \mathrm{CO}_{3}$, EDTA. The strip efficiency was figured out using Equation (2):

$$
D \%=\frac{C_{\mathrm{D}} \times V_{\mathrm{D}}}{q_{\mathrm{e}}} \times 100
$$

where $C_{\mathrm{D}}$ is uranium concentration in eluate $(\mathrm{mg} / \mathrm{L}) . V_{\mathrm{D}}$ is the volume of the collected eluate (L). $q_{e}$ is the uptake amount before strip $(\mathrm{mg} / \mathrm{g})$.

For the recycling experiments, the recovered $\mathrm{MnO}_{2}$-PVA/PAA or PVA/PAA regenerated using $\mathrm{HCl}(1.0 \mathrm{~mol} / \mathrm{L})$ was applied to adsorb uranium repeatedly.

\section{Results and Discussion}

\subsection{Characterization}

The microscopic morphologies of PVA/PAA and $\mathrm{MnO}_{2}-\mathrm{PVA} / \mathrm{PAA}$ are shown in Figure 1(a), Figure 1(b). One can see that both nanofibers were non-directional homogeneous fiber beams without beads. The average diameter were $270 \mathrm{~nm}$ for $\mathrm{PVA} / \mathrm{PAA}$ and $320 \mathrm{~nm}$ for $\mathrm{MnO}_{2}-\mathrm{PVA} / \mathrm{PAA}$. The particles on $\mathrm{MnO}_{2}-\mathrm{PVA} / \mathrm{PAA}$ surface were $\mathrm{MnO}_{2}$. The FT-IR spectrum shown in Figure 1(c) displayed the characteristic bands of PVA/PAA at $3340 \mathrm{~cm}^{-1}, 2942 \mathrm{~cm}^{-1}, 1710 \mathrm{~cm}^{-1}, 1090 \mathrm{~cm}^{-1}$ and $850 \mathrm{~cm}^{-1}$ were resulted from vibrations of hydroxyl, $\mathrm{C}-\mathrm{H}$ asymmetric, $\mathrm{C}=\mathrm{O}$ in carboxyl and ester groups, $\mathrm{C}-\mathrm{O}-\mathrm{C}$ from the crosslinking reaction of PVA and PAA stretching and C-H bending. The FT-IR spectrum of $\mathrm{MnO}_{2}$-PVA/PAA retained the characteristic bands of PVA/PAA and meanwhile highlighted characteristic bands of $\mathrm{MnO}_{2}$ at $1370 \mathrm{~cm}^{-1}$ and $559 \mathrm{~cm}^{-1}$ assigned as stretching vibration of $\mathrm{Mn}-\mathrm{OH}$ and $\mathrm{Mn}-\mathrm{O}$. XRD patterns shown in Figure $1(\mathrm{~d})$ indicated $\mathrm{MnO}_{2}$ indeed existed in $\mathrm{MnO}_{2}$-PVA/PAA according to PDF\#44-0092. The stress-strain curve of PVA/PAA and $\mathrm{MnO}_{2}-\mathrm{PVA} / \mathrm{PAA}$ are shown in Figure 1(e), Figure 1(f). As can be seen, as the immersion duration increased, stress-strain of PVA/PAA and $\mathrm{MnO}_{2}$-PVA/PAA decreased. The reason was attributed to the corrosion from the aqueous solution. 
(a)

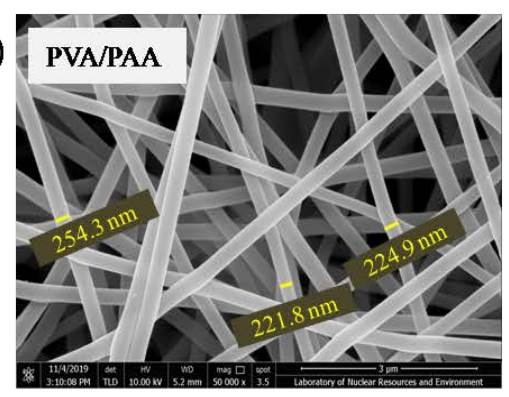

(d)

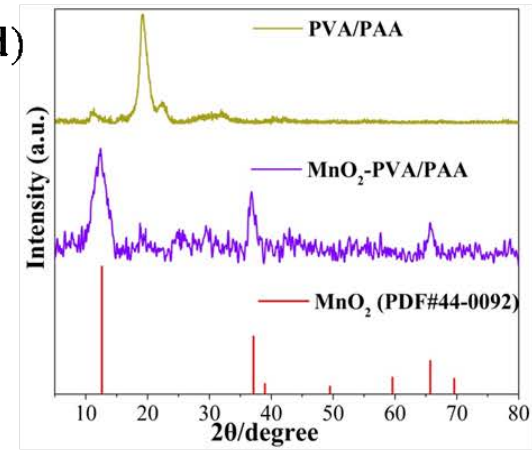

(b)
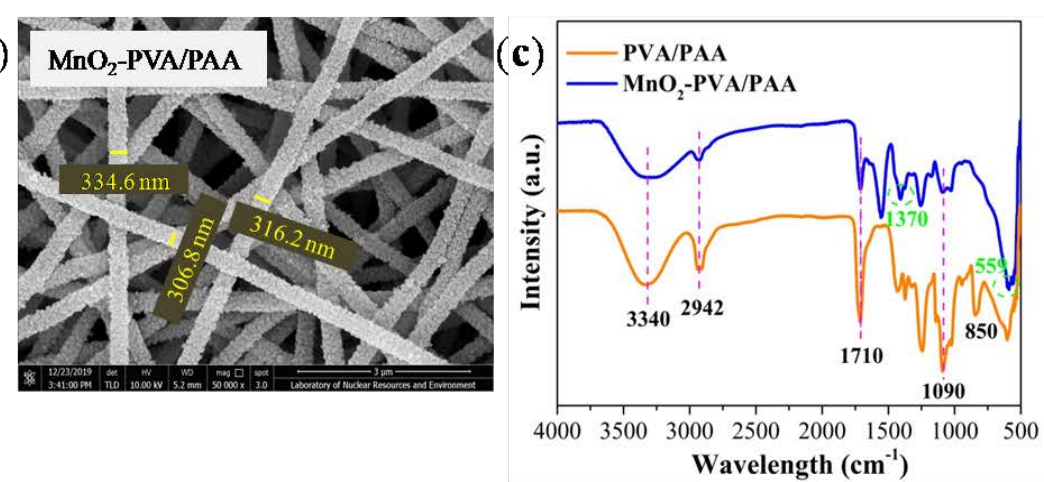
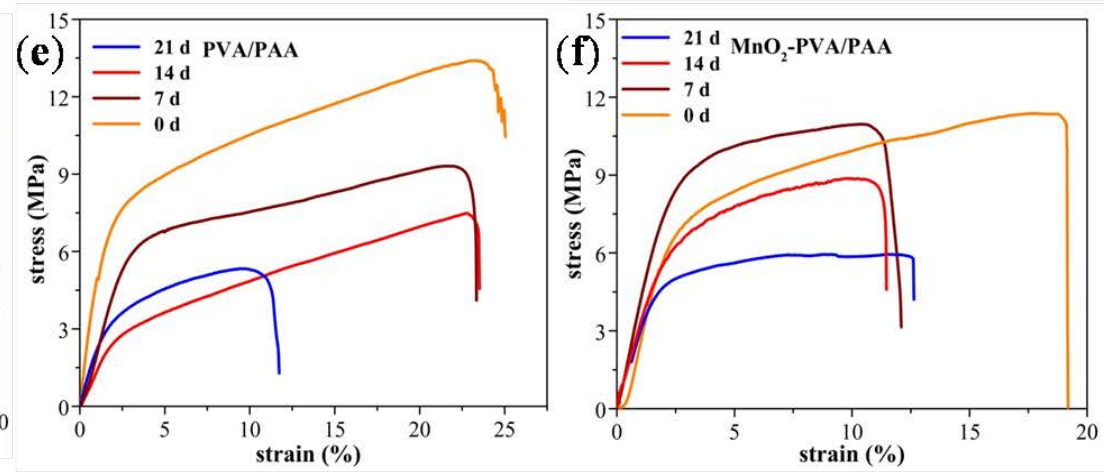

Figure 1. SEM images of (a) PVA/PAA, (b) $\mathrm{MnO}_{2}$-PVA/PAA; (c) FT-IR spectra of PVA/PAA and $\mathrm{MnO}_{2}$-PVA/PAA; (d) XRD patterns of PVA/PAA and $\mathrm{MnO}_{2}$-PVA/PAA; Stress-strain curves of PVA/PAA (e) and $\mathrm{MnO}_{2}$-PVA/PAA (f).

\subsection{Effect of pH and Ionic Strength on Uranium Adsorption}

The uranium uptake amount varying with $\mathrm{pH}$ is shown in Figure 2(a). It can be seen that $\mathrm{pH}$ increasing from 2.5 to 6.0 was beneficial for uranium adsorption. The further increase in $\mathrm{pH}$ would count against the adsorption. The explanation for the results was as following. Firstly positive charged species such as $\mathrm{UO}_{2}{ }^{2+}$, $\mathrm{UO}_{2}(\mathrm{OH})^{+},\left(\mathrm{UO}_{2}\right)_{2}(\mathrm{OH})_{2}{ }^{2+},\left(\mathrm{UO}_{2}\right)_{3}(\mathrm{OH})_{4}{ }^{2+},\left(\mathrm{UO}_{2}\right)_{3}(\mathrm{OH})_{5}{ }^{+}$and $\left(\mathrm{UO}_{2}\right)_{4}(\mathrm{OH})_{7}{ }^{+}$ were dominant at $\mathrm{pH}<6.0$, which showed high affinity toward both nanofibers. Secondly more hydrogen ion at lower $\mathrm{pH}$ could weaken the adsorption ability through protonating the nanofibers and occupying the adsorption sites.

Effect of $\mathrm{NaClO}_{4}$ concentration in the range of $0 \mathrm{~mol} / \mathrm{L}$ to $0.6 \mathrm{~mol} / \mathrm{L}$ on the adsorption is conducted to illustrate the ionic strength influence and the result is shown in Figure 2(b). It can be seen that as $\mathrm{NaClO}_{4}$ concentration increased, the uranium adsorption on both fibers varied slightly. The result proved that the adsorption of uranium on both fibers werein the way of the inner-sphere surface complex [31]. The finding agreed with other uranium adsorption phenomenon reported in the literature [32].

\subsection{Adsorption Isotherms}

Effect of initial uranium concentration on the adsorption onto PVA/PAA and $\mathrm{MnO}_{2}-\mathrm{PVA} / \mathrm{PAA}$ are shown in Figure 3. It can be seen that $q_{\mathrm{e}}$ increased with the increase in $C_{\mathrm{e}}$. The reasonable explanation was that higher concentration gradient promoted the utilization in adsorption sites. To explain the adsorption 

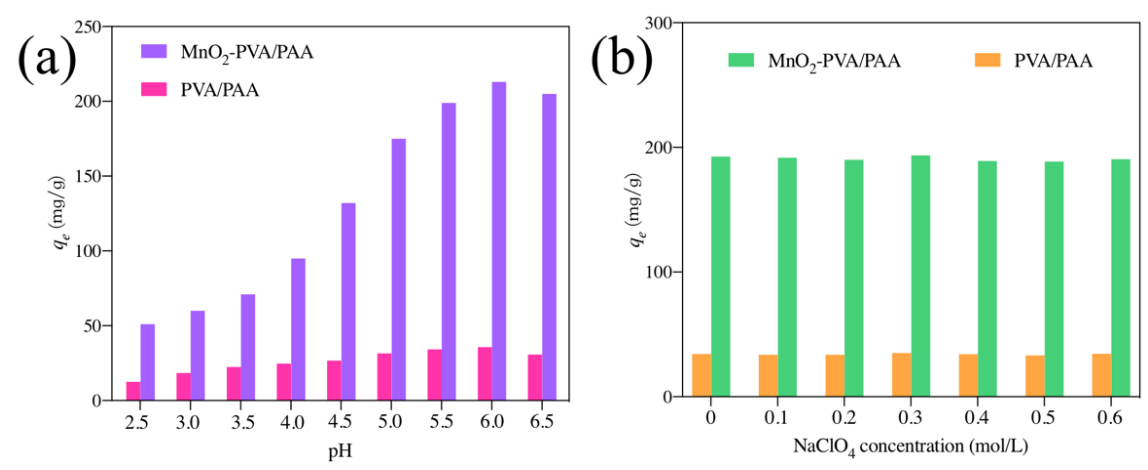

Figure 2. (a) Effect of $\mathrm{pH}$ on uranium adsorption onto PVA/PAA and $\mathrm{MnO}_{2}-\mathrm{PVA} / \mathrm{PAA}$ $\left(C_{0}=50 \mathrm{mg} / \mathrm{L}, V=50 \mathrm{~mL}, m=10 \mathrm{mg}\right.$, mixing time $\left.=2 \mathrm{~h}, T=298.15 \mathrm{~K}\right)$; (b) Effect of ionic strength on uranium adsorption $\left(C_{0}=50 \mathrm{mg} / \mathrm{L}, m=10 \mathrm{mg}, V=50 \mathrm{~mL}, \mathrm{pH}=6.0\right.$, mixing time $=2 \mathrm{~h}, T=298.15 \mathrm{~K})$.

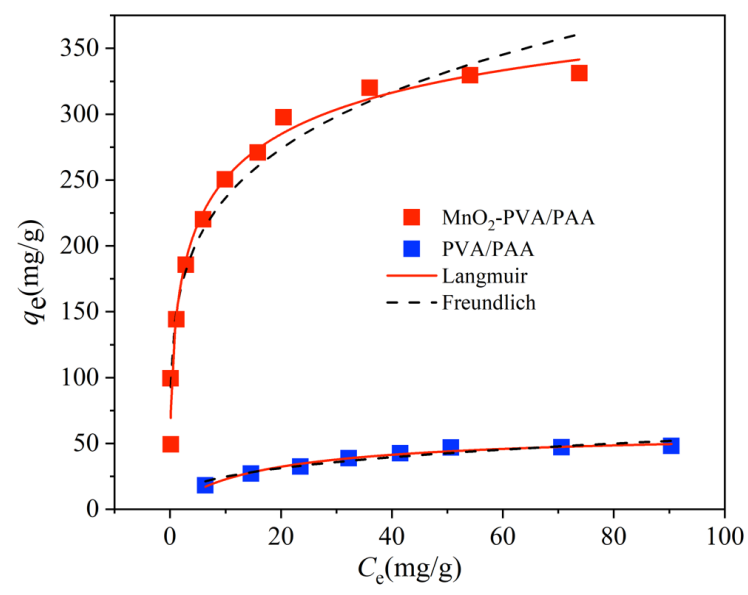

Figure 3. Effect of initial $\mathrm{U}$ (VI) concentration on adsorption capacity. ( $m=10 \mathrm{mg}, V=$ $50 \mathrm{~mL}, \mathrm{pH}=6.0$, mixing time $=2 \mathrm{~h}, T=298.15 \mathrm{~K})$.

mechanism, the data were further analyzed by fitting Langmuir and Freundlich isotherm models.

The Langmuir model is associated with identical active sites and surface coverage in the way of single layer. Its mathematical description is shown in Equation (3):

$$
q_{e}=\frac{K_{L} q_{m} C_{e}}{1+K_{L} C_{e}}
$$

where $C_{e}(\mathrm{mg} / \mathrm{L})$ and $q_{e}(\mathrm{mg} / \mathrm{g})$ are uranium concentration and uptake amount at equilibrium state; $q_{\max }(\mathrm{mg} / \mathrm{g})$ is the theoretically saturation uptake amount; $b$ $(\mathrm{L} / \mathrm{mol})$ is the Langmuir constant.

The Freundlich model fits well with the adsorption on hetergeneous adsorption sites. Its empirically mathematical equation is presented as Equation (4).

$$
q_{e}=K_{F} C_{e}^{1 / n}
$$

where $n(\mathrm{mg} / \mathrm{g})$ and $K_{F}\left(\mathrm{~mol}^{1-n} \cdot \mathrm{L}^{n} / \mathrm{g}\right)$ are used to measure adsorption intensity and uptake amount, respectively. 
As can be seen from Table 1, $R^{2}$ values of the Langmuir model were closer to 1.0 than the values of Freundlich. It could be concluded that the adsorption processes were in agreement with the assumption of Langmuir model. Both adsorption processes took the monolayer way. The modification using $\mathrm{MnO}_{2}$ significantly improved the adsorption amount from $58.51 \mathrm{mg} / \mathrm{g}$ to $398.85 \mathrm{mg} / \mathrm{g}$.

The theoretical $q_{\mathrm{e}}$ of $\mathrm{MnO}_{2}$-PVA/PAA achieved to $398.85 \mathrm{mg} / \mathrm{g}$, a very competitive value compared with other adsorbent materials (shown in Table 2). The competitive $q_{\mathrm{e}}$ of $\mathrm{MnO}_{2}$-PVA/PAA might originated from high disperse of $\mathrm{MnO}_{2}$ on PVA/PAA surface proved in Figure 1(b).

\subsection{Adsorption Kinetics}

Figure 4 shows the effect of mixing time on adsorption of U (VI) with PVA/PAA and $\mathrm{MnO}_{2}$-PVA/PAA. It can be found that the variation in $q_{\mathrm{e}}$ presented three phases including: 1) the rapid boost stage within $0-20$ min resulted from abundant unoccupied sites; 2) the slow increase stage between $20 \mathrm{~min}-120$ min due to insufficient adsorption sites; 3 ) the steady stage after $120 \mathrm{~min}$ attributed to the dynamic state equilibrium.

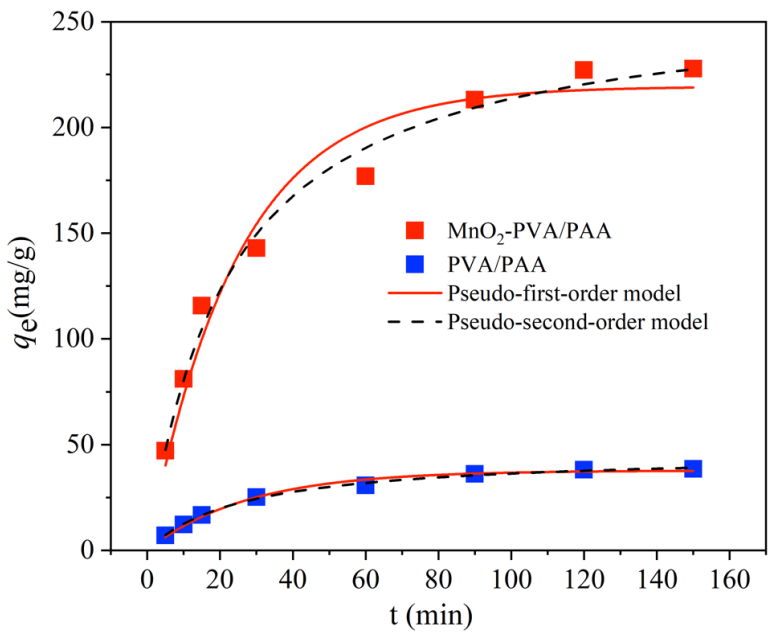

Figure 4. Effect of mixing time on adsorption capacity. ( $C_{0}=50 \mathrm{mg} / \mathrm{L}, m=10 \mathrm{mg}, V=50$ $\mathrm{mL}, \mathrm{pH}=6.0, T=298.15 \mathrm{~K})$.

Table 1. The parameters of Langmuir and Freundlich isotherm models for uranium adsorption on PVA/PAA and $\mathrm{MnO}_{2}$-PVA/PAA.

\begin{tabular}{ccc}
\hline Parameters & $\mathrm{MnO}_{2}$-PVA/PAA & PVA/PAA \\
\hline & Langmuir & \\
$\mathrm{q}_{\max }(\mathrm{mg} / \mathrm{g})$ & 398.85 & 58.51 \\
$\mathrm{~b}(\mathrm{~L} / \mathrm{mol})$ & 0.004 & 0.032 \\
$\mathrm{R}^{2}$ & 0.995 & 0.983 \\
\hline & Freundlich & \\
$\mathrm{K}_{\mathrm{F}}\left(\mathrm{mol}^{1-n} \cdot \mathrm{L}^{n} / \mathrm{g}\right)$ & 23.01 & 8.91 \\
$1 / \mathrm{n}$ & 0.46 & 0.38 \\
$\mathrm{R}^{2}$ & 0.935 & 0.919 \\
\hline
\end{tabular}


Table 2. The maximal adsorption capacity of various sorbents for uranium.

\begin{tabular}{cccc}
\hline Adsorbents & Experimental parameters & Qmax $(\mathrm{mg} / \mathrm{g})$ & Reference \\
\hline HMO & $\mathrm{pH}=5.0, \mathrm{~T}=298 \mathrm{~K}$ & 57.6 & {$[33]$} \\
SBA-15 & $\mathrm{pH}=6.0, \mathrm{~T}=298 \mathrm{~K}$ & 203 & {$[34]$} \\
NIMS-4 & $\mathrm{pH}=6.0, \mathrm{~T}=298 \mathrm{~K}$ & 79.2 & {$[35]$} \\
CNFs & $\mathrm{pH}=4.5, \mathrm{~T}=298 \mathrm{~K}$ & 125 & {$[36]$} \\
U-PASS & $\mathrm{pH}=5.0, \mathrm{~T}=303 \mathrm{~K}$ & 147.8 & {$[37]$} \\
DSHM-DAMN & $\mathrm{pH}=8.0, \mathrm{~T}=298 \mathrm{~K}$ & 601 & {$[38]$} \\
HGly & $\mathrm{pH}=5.0, \mathrm{~T}=293 \mathrm{~K}$ & 186.5 & {$[39]$} \\
PVP/chitosan & $\mathrm{pH}=5.9, \mathrm{~T}=298 \mathrm{~K}$ & 167 & {$[40]$} \\
PAF & $\mathrm{pH}=5.0, \mathrm{~T}=303 \mathrm{~K}$ & 115.31 & {$[41]$} \\
Magnetic biochar & $\mathrm{pH}=4.0, \mathrm{~T}=318 \mathrm{~K}$ & 52.63 & {$[42]$} \\
Polypyrrole & $\mathrm{pH}=5.0, \mathrm{~T}=298 \mathrm{~K}$ & 87.72 & {$[43]$} \\
P(AO)-g-CTS/BT & $\mathrm{pH}=8.0, \mathrm{~T}=298 \mathrm{~K}$ & 49.09 & {$[44]$} \\
Fe-Al LDHs & $\mathrm{pH}=6.0, \mathrm{~T}=298 \mathrm{~K}$ & 99.01 & {$[45]$} \\
MnO -PVA/PAA & $\mathrm{pH}=6.0, \mathrm{~T}=298 \mathrm{~K}$ & 398.85 & this study \\
\hline
\end{tabular}

To illuminate kinetics process in detail, two frequently used models, pseudo-first-order Equation (5) and pseudo-second-order Equation (6) kinetics equations, were adopted to fit the data.

$$
\begin{gathered}
q_{t}=q_{e}\left(1-e^{-k_{1} t}\right) \\
q_{t}=\frac{q_{e}^{2} k_{2} t}{1+q_{e} k_{2} t}
\end{gathered}
$$

where $q_{t}\left(\mathrm{mg} \cdot \mathrm{g}^{-1}\right)$ and $q_{e}\left(\mathrm{mg} \cdot \mathrm{g}^{-1}\right)$ are the uptake amount at time $t(\mathrm{~min})$ and equilibrium, respectively; $k_{1}\left(\mathrm{~min}^{-1}\right)$ and $k_{2}\left(\mathrm{~g} \cdot \mathrm{mg}^{-1} \cdot \mathrm{min}^{-1}\right)$ represent adsorption rate constants, respectively.

The fitting values are listed in Table 3 . It can be clearly seen that: 1) the correlation coefficients values derived from the pseudo-second-order kinetics (0.997 for PVA/PAA and 0.987 for $\mathrm{MnO}_{2}$-PVA/PAA) were closer to 1.0 than the pseudo-first-order kinetics (0.987 for PVA/PAA and 0.957 for $\mathrm{MnO}_{2}$-PVA/PAA); 2) the experimentally maximal uptake amounts $(38.52 \mathrm{mg} / \mathrm{g}$ for PVA/PAA and $227.87 \mathrm{mg} / \mathrm{g}$ for $\mathrm{MnO}_{2}$-PVA/PAA) were more approximate to the theoretical values $\left(42.16 \mathrm{mg} / \mathrm{g}\right.$ for PVA/PAA and $242.56 \mathrm{mg} / \mathrm{g}$ for $\left.\mathrm{MnO}_{2}-\mathrm{PVA} / \mathrm{PAA}\right)$ from the pseudo-second-order kinetics rather than the theoretical values $(33.04 \mathrm{mg} / \mathrm{g}$ for PVA/PAA and $193.29 \mathrm{mg} / \mathrm{g}$ for $\mathrm{MnO}_{2}$-PVA/PAA) from the pseudo-first-order kinetics. The consequent parameters proved both adsorption processes were coincide with the assumption of the pseudo-second-order kinetics. The results indicated both adsorption processes are mainly chemical.

\subsection{Adsorption Thermodynamics}

The effect of temperature $(288.15 \mathrm{~K}-318.15 \mathrm{~K})$ on the adsorption of uranium 
Table 3. The calculated parameters of pseudo-first-order and pseudo-second-order models fitting the adsorption of uranium on PVA/PAA and $\mathrm{MnO}_{2}$-PVA/PAA.

\begin{tabular}{|c|c|c|c|c|c|c|c|}
\hline \multirow{2}{*}{ Materials } & \multirow{2}{*}{$\begin{array}{c}q_{\mathrm{e}, \exp } \\
(\mathrm{mg} / \mathrm{g})\end{array}$} & \multicolumn{3}{|c|}{ Pseudo-first-order model } & \multicolumn{3}{|c|}{ Pseudo-second-order model } \\
\hline & & $q_{e, \text { cal }}(\mathrm{mg} / \mathrm{g})$ & $k_{1}$ & $R^{2}$ & $q_{e, \text { cal }}(\mathrm{mg} / \mathrm{g})$ & $k_{2}$ & $R^{2}$ \\
\hline PVA/PAA & 38.52 & 33.04 & 0.0364 & 0.987 & 42.16 & $8.24 \times 10^{-4}$ & 0.997 \\
\hline $\mathrm{MnO}_{2}$-PVA/PAA & 227.87 & 193.29 & 0.0405 & 0.957 & 242.56 & $1.69 \times 10^{-4}$ & 0.987 \\
\hline
\end{tabular}

with PVA/PAA and $\mathrm{MnO}_{2}$-PVA/PAA were studied. The results are shown in Figure 5(a). It can be seen that both $q_{\mathrm{e}}$ slightly increased with the increase in temperature. It is revealed that a higher temperature favored the adsorption.

To study the thermodynamic nature of the adsorption, the thermodynamic parameters such as $\Delta H^{\circ}$ and $\Delta S^{\circ}$ were calculated out by Equation (7) from the slope and intercept of the linear plot between $\ln K_{d} v s .1 / T$. The change in Gibbs free energy $\Delta G^{\circ}$ values was acquired using Equation (8).

$$
\begin{gathered}
\ln K_{d}=\frac{\Delta S^{\circ}}{R}-\frac{\Delta H^{\circ}}{R T} \\
\Delta G^{\circ}=\Delta H^{\circ}-T \Delta S^{\circ}
\end{gathered}
$$

where $K_{d}\left(\mathrm{~mL} \cdot \mathrm{g}^{-1}\right)$ is the distribution coefficient at the equilibrium state; $R(8.314$ $\left.\mathrm{J} \cdot \mathrm{K}^{-1} \cdot \mathrm{mol}^{-1}\right)$ is the ideal gas constant; $T(\mathrm{~K})$ is thermodynamic Kelvin temperature.

$\ln K_{\mathrm{d}}$ as a function of $1 / T$ is shown in Figure 5(b). The obtained values are listed in Table 4. $\Delta H^{\circ}$ and $\Delta S^{\circ}$ of positivity indicated both adsorption were endothermic processes with entropy increase. The negative $\Delta G^{\circ}$ values proved that both adsorptions were spontaneous. A higher temperature leading to a higher absolute value of $\Delta G^{\circ}$ illustrated that increasing temperature promoted the adsorption process. In addition, the absolute value of $\Delta G^{\circ}$ for $\mathrm{MnO}_{2}$-PVA/PAA was greater than that of PVA/PAA, indicating that $\mathrm{MnO}_{2}$-PVA/PAA was more likeable for $\mathrm{U}(\mathrm{VI})$ than PVA/PAA.

\subsection{Desorption, Reusability}

The reusability is an important indicator for the practical application of a material. The desorption behavior of PVA/PAA and $\mathrm{MnO}_{2}$-PVA/PAA were studied using stripping reagents such as $\mathrm{HCl}, \mathrm{H}_{2} \mathrm{SO}_{4}, \mathrm{HNO}_{3}, \mathrm{Na}_{2} \mathrm{CO}_{3}$ and ethylenediaminetetraacetic acid (EDTA) of $1.0 \mathrm{~mol} \cdot \mathrm{L}^{-1}$. The desorption rate $\mathrm{D} \%$ are shown in Figure 6(a). It is found that $\mathrm{HCl}$ solution had the most efficient strip ability. The reason maybe that $\mathrm{Cl}^{-}$with stronger polarity combined with $\mathrm{UO}_{2}^{2+}$ to form $\mathrm{UO}_{2} \mathrm{Cl}_{3}^{-}$readily. $\mathrm{HCl}$ solution was thus used for the next adsorption-desorption cycle experiments.

The adsorption-desorption cycle experiments was conducted to assess the reusability of $\mathrm{MnO}_{2}$-PVA/PAA. $\mathrm{HCl}$ solution of $1.0 \mathrm{~mol} \cdot \mathrm{L}^{-1}$ was used as the desorption reagent. The result is shown in Figure $6(\mathrm{~b})$. It can be seen that the uptake amount $\left(q_{\mathrm{e}}\right)$ decreased as the cycle time increased. The decrease was resulted from the decrease in effective adsorption sites. Firstly $\mathrm{HCl}$ solution could 

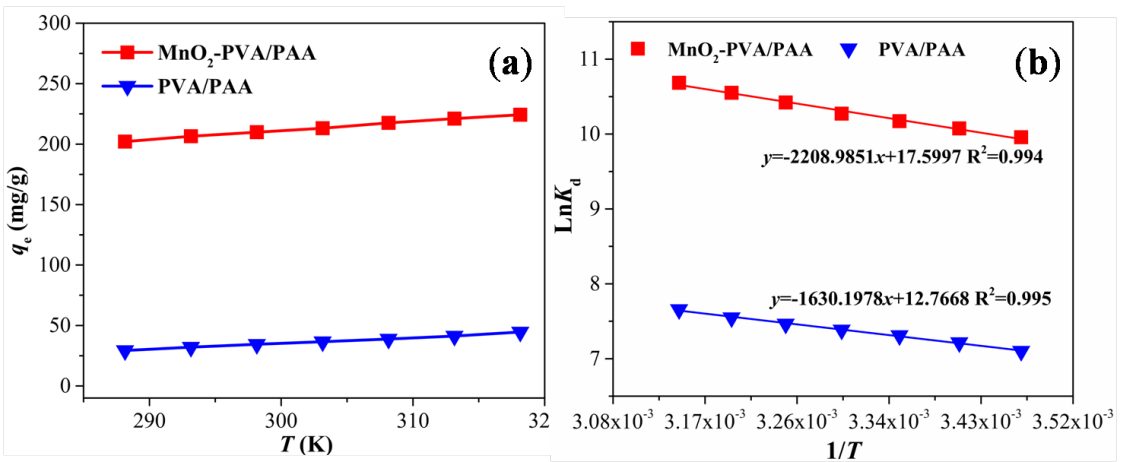

Figure 5. (a) Effect of temperature on adsorption capacity; (b) linear plots of $\ln K_{\mathrm{d}} v s .1 / T$ $\left(C_{0}=50 \mathrm{mg} / \mathrm{L}, m=10 \mathrm{mg}, V=50 \mathrm{~mL}, \mathrm{pH}=6.0\right.$, mixing time $=2 \mathrm{~h}$ ).
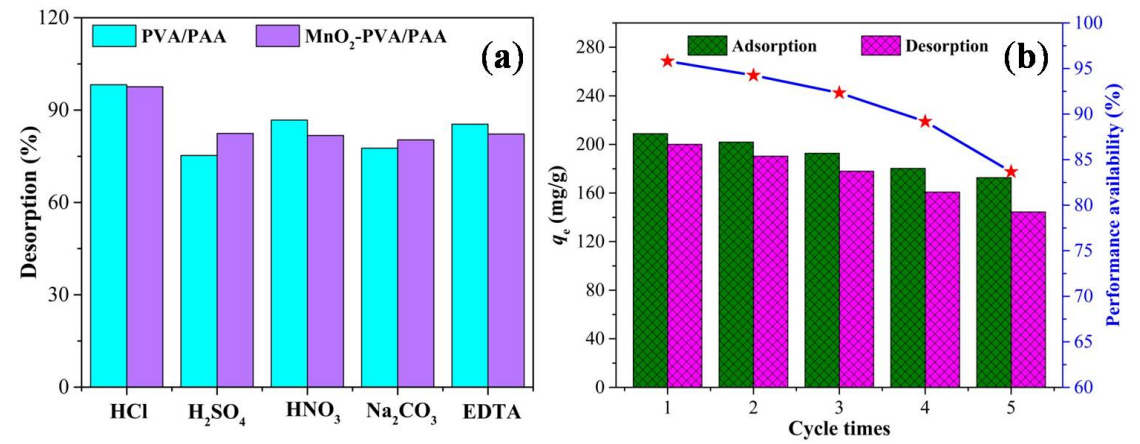

Figure 6. (a) Desorption efficiency of many eluents; (b) Reusing performance of $\mathrm{MnO}_{2}$-PVA/PAA. $\left(\mathrm{C}_{0}=50 \mathrm{mg} / \mathrm{L}, \mathrm{m}=10 \mathrm{mg}, \mathrm{pH}=6.0\right.$, mixing time $=2 \mathrm{~h}, \mathrm{~T}=298.15 \mathrm{~K}$.

Table 4. Thermodynamic parameters of adsorption of uranium onto PVA/PAA and $\mathrm{MnO}_{2}-\mathrm{PVA} / \mathrm{PAA}$.

\begin{tabular}{cccc}
\hline Parameters & Temperature (K) & PVA/PAA & MnO $_{2}$-PVA/PAA \\
\hline$\Delta \mathrm{H}^{\circ}\left(\mathrm{kJ} \cdot \mathrm{mol}^{-1}\right)$ & - & 13.55 & 18.37 \\
$\Delta S^{\circ}\left(\mathrm{J} \cdot \mathrm{K}^{-1} \cdot \mathrm{mol}^{-1}\right)$ & - & 106.04 & 146.32 \\
& 288.15 & -17.03 & -23.79 \\
& 293.15 & -17.56 & -24.52 \\
& 298.15 & -18.10 & -25.26 \\
$\Delta G^{\circ}\left(\mathrm{kJ} \cdot \mathrm{mol}^{-1}\right)$ & 303.15 & -18.63 & -25.99 \\
& 308.15 & -19.16 & -26.72 \\
& 313.15 & -19.69 & -27.45 \\
& 318.15 & -20.22 & -28.18 \\
\hline
\end{tabular}

not completely desorb all the uranium adsorbed on $\mathrm{MnO}_{2}$-PVA/PAA; Secondly the adsorption in the chemical way of the inner-sphere surface complex was not fully reversible. Even so $q_{\mathrm{e}}$ decreased from the initial $208.87 \mathrm{mg} / \mathrm{g}$ to the final $172.65 \mathrm{mg} / \mathrm{g}$ after five cycles.

\subsection{Mechanism Explored with XPS}

To explore the interaction of uranyl with $\mathrm{MnO}_{2}$-PVA/PAA in the molecular lev- 
el, XPS was used to reveal the binding energy of $\mathrm{MnO}_{2}-\mathrm{PVA} / \mathrm{PAA}$ and $\mathrm{MnO}_{2}-\mathrm{PVA} / \mathrm{PAA}-\mathrm{U}(\mathrm{VI})$. $\mathrm{C}, \mathrm{O}$ and $\mathrm{Mn}$, the major composition of $\mathrm{MnO}_{2}-\mathrm{PVA} / \mathrm{PAA}$, were verified by $\mathrm{C} 1 \mathrm{~s}, \mathrm{O} 1 \mathrm{~s}$ and $\mathrm{Mn} 2 \mathrm{p}$ peaks in Figure 7. Due to the characteristic doublet of $\mathrm{U}$ 4f (shown in Figure 7(a), Figure 7(e)), it was no doubt that uranium had been adsorbed on the near-surface of $\mathrm{MnO}_{2}$-PVA/PAA. As can be seen in Figure $7(\mathrm{e}), \mathrm{U} 4 \mathrm{f}$ was splitted into $\mathrm{U} 4 \mathrm{f}_{5 / 2}$ and $\mathrm{U} 4 \mathrm{f}_{7 / 2}$, of which the former corresponded to $\mathrm{U}-\mathrm{O}$ in uranyl and the latter was attributed to uranium atom binding with the oxygen atom in manganese dioxide.

The $\mathrm{C}$ 1s signals (shown in Figure 7(d)) was deconvoluted into three peaks at $288.52 \mathrm{eV}, 285.65 \mathrm{eV}$ and $284.53 \mathrm{eV}$ assigned to carbon in $\mathrm{C}=\mathrm{O}, \mathrm{C}-\mathrm{O}$ and $\mathrm{C}-\mathrm{C}$ bonds, in which the former chemical bonds slightly shifted to $288.57 \mathrm{eV}$ and $285.71 \mathrm{eV}$ owing to the participation of oxygen in interaction with uranium.

The Mn $2 p$ signal shown in Figure 7 (c) presented as Mn 2 $p_{1 / 2}$ and $M n 2 p_{3 / 2}$ corresponding to the $\mathrm{Mn}-\mathrm{O}$ bond. The slight change in binding energy proved that manganese did not directly interact with uranium.

Obvious distinct are observed in the spectrum of O 1s (shown in Figure 7(b)). Indetail, the $\mathrm{O} 1 \mathrm{~s}$ signal was splitted into four peaks originally positioned at $532.89 \mathrm{eV}, 531.73 \mathrm{eV}, 531.27 \mathrm{eV}$ and $529.39 \mathrm{eV}$ assigned as $\mathrm{C}-\mathrm{O}, \mathrm{C}=\mathrm{O}, \mathrm{Mn}-\mathrm{O}-\mathrm{H}$ and $\mathrm{Mn}-\mathrm{O}-\mathrm{Mn}$. After adsorption, the binding energy changed obviously and the relative intensity of four peaks varied significantly. The obvious distinct proved oxygen atom was the major donor atom. The adsorption mechanism of uranium onto $\mathrm{MnO}_{2}$-PVA/PAA is thus proposed as Figure 7(f). Namely the fixed uranyl
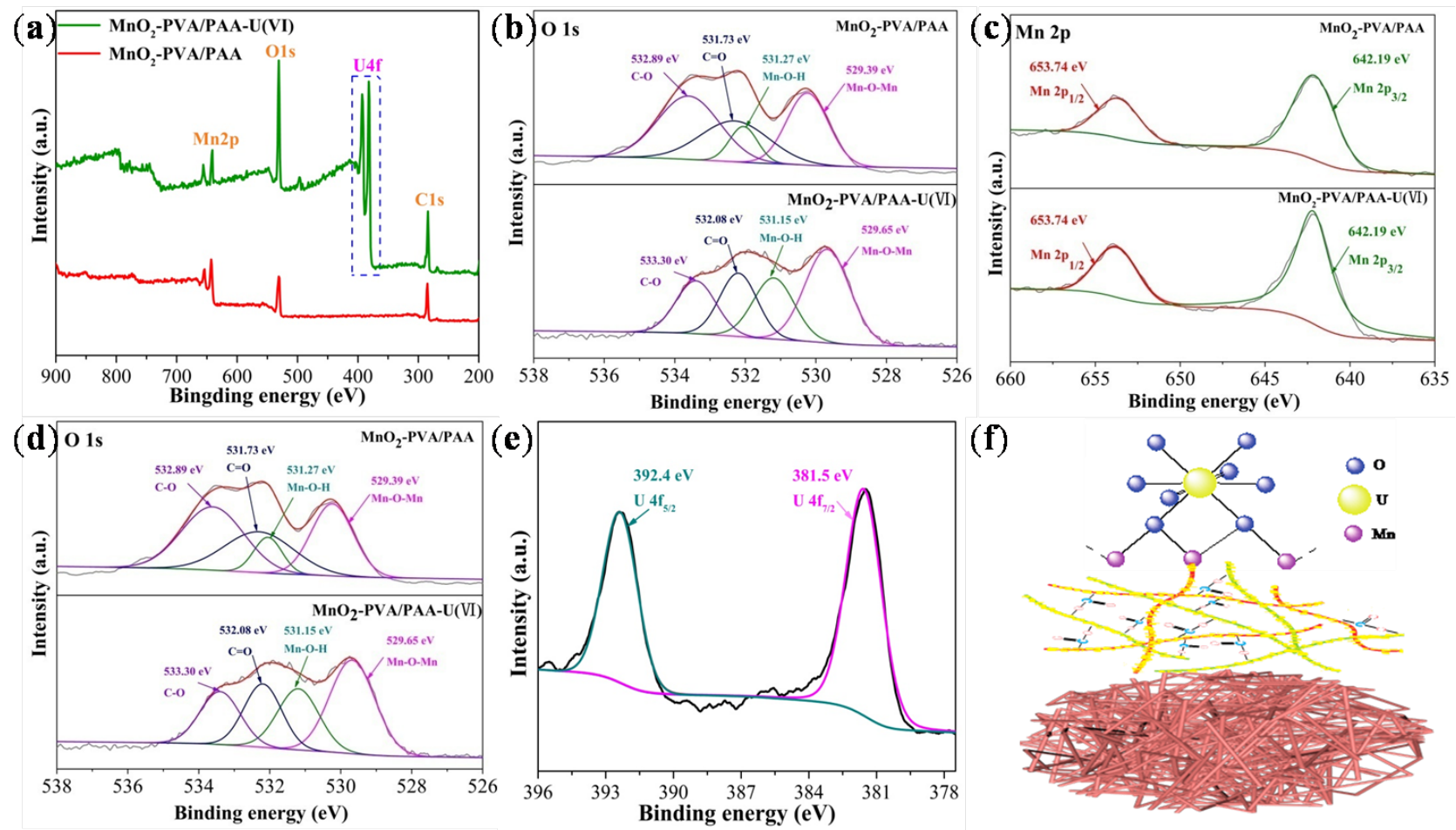

(f)

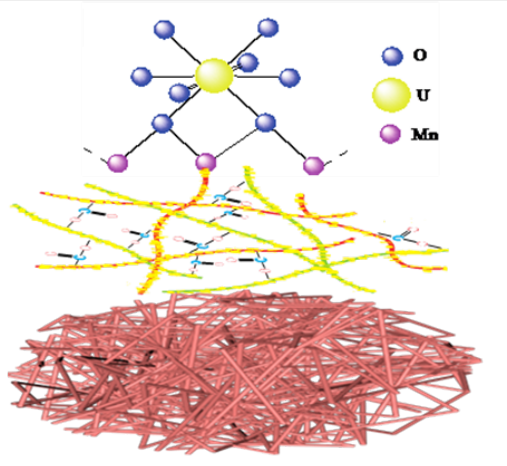

Figure 7. XPS spectra (a) full spectrum, (b) O 1s, (c) Mn 2P, (d) C 1s, and (e) U 4f of $\mathrm{MnO}_{2}-\mathrm{PVA} / \mathrm{PAA}$ and $\mathrm{MnO}_{2}-\mathrm{PVA} / \mathrm{PAA}-\mathrm{U}(\mathrm{VI})$; (f) The proposal mechanism of uranium interacting with $\mathrm{MnO}_{2}-\mathrm{PVA} / \mathrm{PAA}$. 
with $\mathrm{MnO}_{2}$-PVA/PAA was anchored with two oxygen atoms in manganese dioxide.

\section{Conclusion}

In the study a novel manganese dioxide modified nanofiber, $\mathrm{MnO}_{2}-\mathrm{PVA} / \mathrm{PAA}$, was facile prepared using the electrospinning technique. $\mathrm{MnO}_{2}$-PVA/PAA was proved by SEM, FT-IR, XRD, stress-strain test. Effect of $\mathrm{pH}$, ionic strength, initial uranium concentration, mixing time, temperature on the adsorption, reusability and adsorption mechanism were illustrated. The optimal $\mathrm{pH}$ was determined as 6.0. The adsorption took the way of inner-sphere surface complex. The theoretical adsorption amount of $\mathrm{MnO}_{2}$-PVA/PAA calculated as $398.85 \mathrm{mg} / \mathrm{g}$. The pseudo-second-order kinetics well fitted the adsorption process, illustrating chemical mode. The thermodynamic parameter $\Delta H^{\circ}$ and $\Delta S^{\circ}$ were 13.55 $\mathrm{kJ} \cdot \mathrm{mol}^{-1}$ and $106.04 \mathrm{~J} \cdot \mathrm{K}^{-1} \cdot \mathrm{mol}^{-1}$. The absolute value of $\Delta G^{\circ}$ increased as the temperature increased. XPS revealed that uranyl complexed $\mathrm{MnO}_{2}$-PVA/PAA through the U-O-Mn bond. The results herein demonstrated high potential of $\mathrm{MnO}_{2}$-PVA/PAA as a candidate in separation for uranium.

\section{Acknowledgements}

This work was financially supported by the National Natural Science Foundation of China (22066001).

\section{Conflicts of Interest}

The authors declare no conflicts of interest regarding the publication of this paper.

\section{References}

[1] Abas, N., Kalair, A. and Khan, N.J.F. (2015) Review of Fossil Fuels and Future Energy Technologies. Futures, 69, 31-49. https://doi.org/10.1016/j.futures.2015.03.003

[2] Hore-Lacy, I. (2016) Uranium for Nuclear Power: An Introduction, Uranium for Nuclear Power. 1st Edition, Woodhead Publishing Ltd., Cambridge, 3-10. https://doi.org/10.1016/B978-0-08-100307-7.00001-6

[3] Tao, Q.Q., Zhang, X., Prabaharan, K. and Dai, Y. (2019) Separation of Cesium from Wastewater with Copper Hexacyanoferrate Film in an Electrochemical System Driven by Microbial Fuel Cells. Bioresour. Technol., 278, 456-459. https://doi.org/10.1016/j.biortech.2019.01.093

[4] Ma, F., Gui, Y., Liu, P., Xue, Y. and Song, W. (2020) Functional Fibrous Materials-Based Adsorbents for Uranium Adsorption and Environmental Remediation. Chem. Eng. J., 390, 124597. https://doi.org/10.1016/j.cej.2020.124597

[5] Singh, D., Hareendran, K., Sreenivas, T., Kain, V. and Dey, G. (2017) Development of a Phosphate Precipitation Method for the Recovery of Uranium from Lean Tenor Alkaline Leach Liquor. Hydrometallurgy, 171, 228-235. https://doi.org/10.1016/j.hydromet.2017.05.021 
[6] Prabhu, D.R., Mohapatra, P.K., Raut, D.R., Pathak, P. and Billard, I. (2017) Extraction of Uranium (VI) from Nitric Acid Solutions Using N, N-Dihexyloctanamide in Ionic Liquids: Solvent Extraction and Spectroscopic Studies. Solvent Extr. Ion Exch. 35, 423-438. https://doi.org/10.1080/07366299.2017.1377423

[7] Amphlett, J.T.M., Choi, S., Parry, S.A., Moon, E.M., Sharrad, C.A. and Ogden, M.D. (2019) Insights on Uranium Uptake Mechanisms by Ion Exchange Resins with Chelating Functionalities: Chelation vs. Anion Exchange. Chem. Eng. J., 392, 123712. https://doi.org/10.1016/j.cej.2019.123712

[8] Jung, Y., Kim, S., Park, S.J. and Kim, J.M. (2008) Application of Polymer-Modified Nanoporous Silica to Adsorbents of Uranyl Ions. Colloid Surf. A: Physicochem. Eng. Asp., 313, 162-166. https://doi.org/10.1016/j.colsurfa.2007.04.087

[9] Bessbousse, H., Rhlalou, T., Verchère, J.F. and Lebrun, L. (2008) Removal of Heavy Metal Ions from Aqueous Solutions by Filtration with a Novel Complexing Membrane Containing Poly (Ethyleneimine) in a Poly (Vinyl Alcohol) Matrix. J. Membr. Sci., 307, 249-259. https://doi.org/10.1016/j.memsci.2007.09.027

[10] Liang, P.L., Yuan, L.Y., Deng, H., Wang, X.C., Wang, L., Li, Z.J., Luo, S.Z. and Shi, W.Q. (2020) Photocatalytic Reduction of Uranium (VI) by Magnetic $\mathrm{ZnFe}_{2} \mathrm{O}_{4}$ under Visible Light. Applied Catalysis B: Environmenta, 267, 118688. https://doi.org/10.1016/j.apcatb.2020.118688

[11] Li, F.F., Cui, W.R., Jiang, W., Zhang, C.R., Liang, R.P. and Qiu, J.D. (2020) Stable sp ${ }^{2}$ Carbon-Conjugated Covalent Organic Framework for Detection and Efficient Adsorption of Uranium from Radioactive Wastewater. J. Hazard. Mater, 392, 122333. https://doi.org/10.1016/j.jhazmat.2020.122333

[12] Drysdale, J.A. and Buesseler, K.O. (2020) Uranium Adsorption Behaviour of Amidoximated Fibers under Coastal Ocean Conditions. Prog. Nucl. Energy, 119, 103170. https://doi.org/10.1016/j.pnucene.2019.103170

[13] Pan, N., Li, L., Ding, J., Li, S., Wang, R., Jin, Y., Wang, X. and Xia, C. (2016) Preparation of Graphene Oxide-Manganese Dioxide for Highly Efficient Adsorption and Separation of Th(IV)/U(VI). J. Hazard. Mater., 309, 107-115. https://doi.org/10.1016/j.jhazmat.2016.02.012

[14] Yang, C., Zhong, Y., Li, L., Ren, X., Sun, Y., Niu, D., Liu, Y., Yin, M. and Zhang, D. (2018) Lead and Uranium Sorption Characteristics on Hydrothermal Synthesized Delta Manganese Dioxide. J. Radioanal. Nucl. Chem., 317, 1399-1408. https://doi.org/10.1007/s10967-018-6004-0

[15] Zhu, Q. and Li, Z. (2015) Hydrogel-Supported Nanosized Hydrous Manganese Dioxide: Synthesis, Characterization, and Adsorption Behavior Study for $\mathrm{Pb}^{2+}, \mathrm{Cu}^{2+}$, $\mathrm{Cd}^{2+}$ and $\mathrm{Ni}^{2+}$ Removal from Water. Chem. Eng. J., 281, 69-80. https://doi.org/10.1016/j.cej.2015.06.068

[16] Kim, E.J., Lee, C.-S., Chang, Y.-Y. and Chang, Y.-S. (2013) Hierarchically Structured Manganese Oxide-Coated Magnetic Nanocomposites for the Efficient Removal of Heavy Metal Ions from Aqueous Systems. ACS Appl. Mater. Interfaces, 5, 9628-9634. https://doi.org/10.1021/am402615m

[17] Xue, J., Wu, T., Dai, Y. and Xia, Y. (2019) Electrospinning and Electrospun Nanofibers: Methods, Materials, and Applications. Chem. Rev., 119, 5298-5415. https://doi.org/10.1021/acs.chemrev.8b00593

[18] Sun, W., Lu, X., Tong, Y., Lei, J., Nie, G. and Wang, C. (2014) A One-Pot Synthesis of a Highly Dispersed Palladium/Polypyrrole/Polyacrylonitrile Nanofiber Membrane and Its Recyclable Catalysis in Hydrogen Generation from Ammonia Borane. J. Mater. Chem. A, 2, 6740-6746. https://doi.org/10.1039/C3TA15441F 
[19] Li, Y., Lee, D.K., Kim, J.Y., Kim, B., Park, N.G., Kim, K., Shin, J.H., Choi, I.S. and Ko, M.J. (2012) Highly Durable and Flexible Dye-Sensitized Solar Cells Fabricated On Plastic Substrates: PVDF-Nanofiber-Reinforced $\mathrm{TiO}_{2}$ Photoelectrodes. Energy Environ. Sci., 5, 8950-8957. https://doi.org/10.1039/c2ee21674d

[20] Gu, X., Ding, F. and Williams, D.F. (2014) Neural Tissue Engineering Options for Peripheral Nerve Regeneration. Biomaterials, 35, 6143-6156.

https://doi.org/10.1016/j.biomaterials.2014.04.064

[21] Selvam, A.K. and Nallathambi, G. (2015) Polyacrylonitrile/Silver Nanoparticle Electrospun Nanocomposite Matrix for Bacterial Filtration. Fiber. Polym., 16, 1327-1335. https://doi.org/10.1007/s12221-015-1327-8

[22] Xie, J.H., Lv, R.W., Peng, H., Fan, J.L., Tao, Q.Q., Dai, Y., Zhang, Z., Cao, X. and Liu, Y.H. (2020) Phosphate Functionalized Poly(Vinyl Alcohol)/Poly(Acrylic Acid) (PVA/PAA): An Electrospinning Nanofiber for Uranium Separation. J. Radioanal. Nucl. Chem., 326, 475-486. https://doi.org/10.1007/s10967-020-07319-x

[23] Dastbaz, A. and Keshtkar, A.R. (2014) Adsorption of $\mathrm{Th}^{4+}, \mathrm{U}^{6+}, \mathrm{Cd}^{2+}$, and $\mathrm{Ni}^{2+}$ from Aqueous Solution by a Novel Modified Polyacrylonitrile Composite Nanofiber Adsorbent Prepared by Electrospinning. Appl. Surf. Sci., 293, 336-344. https://doi.org/10.1016/j.apsusc.2013.12.164

[24] Yari, S., Abbasizadeh, S., Mousavi, S.E., Moghaddam, M.S. and Moghaddam, A.Z. (2015) Adsorption of $\mathrm{Pb}$ (II) and $\mathrm{Cu}$ (II) Ions from Aqueous Solution by an Electrospun $\mathrm{CeO}_{2}$ Nanofiber Adsorbent Functionalized with Mercapto Groups. Process Saf. Environ. Protect., 94, 159-171. https://doi.org/10.1016/j.psep.2015.01.011

[25] Irani, M., Keshtkar, A.R. and Moosavian, M.A. (2012) Removal of Cadmium from Aqueous Solution Using Mesoporous PVA/TEOS/APTES Composite Nanofiber Prepared by Sol-Gel/Electrospinning. Chem. Eng. J., 200, 192-201. https://doi.org/10.1016/j.cej.2012.06.054

[26] Alipour, D., Keshtkar, A.R. and Moosavian, M.A. (2016) Adsorption of Thorium (IV) from Simulated Radioactive Solutions Using a Novel Electrospun PVA/TiO $/ 2 \mathrm{ZnO}$ Nanofiber Adsorbent Functionalized with Mercapto Groups: Study in Single and Multi-Component Systems. Appl. Surf. Sci., 366, 19-29. https://doi.org/10.1016/j.apsusc.2016.01.049

[27] Mahapatra, A., Mishra, B. and Hota, G. (2013) Electrospun $\mathrm{Fe}_{2} \mathrm{O}_{3}-\mathrm{Al}_{2} \mathrm{O}_{3}$ Nanocomposite Fibers as Efficient Adsorbent for Removal of Heavy Metal Ions from Aqueous Solution. J. Hazard. Mater., 258, 116-123. https://doi.org/10.1016/j.jhazmat.2013.04.045

[28] Abbasizadeh, S., Keshtkar, A.R. and Mousavian, M.A. (2013) Preparation of A Novel Electrospun Polyvinyl Alcohol/Titanium Oxide Nanofiber Adsorbent Modified with Mercapto Groups for Uranium (VI) and Thorium (IV) Removal from Aqueous Solution. Chem. Eng. J., 220, 161-171. https://doi.org/10.1016/j.cej.2013.01.029

[29] Beheshti, H., Irani, M., Hosseini, L., Rahimi, A. and Aliabadi, M. (2016) Removal of $\mathrm{Cr}$ (VI) from Aqueous Solutions Using Chitosan/MWCNT/ $/ \mathrm{Fe}_{3} \mathrm{O}_{4}$ Composite Nanofibers-Batch and Column Studies. Chem. Eng. J., 284, 557-564. https://doi.org/10.1016/j.cej.2015.08.158

[30] Aliabadi, M., Irani, M., Ismaeili, J. and Najafzadeh, S. (2014) Design and Evaluation of Chitosan/Hydroxyapatite Composite Nanofiber Membrane for the Removal of Heavy Metal Ions from Aqueous solution. J. Taiwan Inst. Chem. Eng., 45, 518-526. https://doi.org/10.1016/j.jtice.2013.04.016

[31] Zong, P., Wu, X., Gou, J., Lei, X., Liu, D. and Deng, H. (2015) Immobilization and Recovery of Uranium (VI) Using Na-Bentonite from Aqueous Medium: Equilibrium, Kinetics and Thermodynamics Studies. J. Mol. Liq., 209, 358-366. 
https://doi.org/10.1016/j.molliq.2015.05.052

[32] Zhang, J., Guo, Z., Li, Y., Pan, S., Chen, X. and Xu, J. (2016) Effect of Environmental Conditions on the Sorption of Uranium on $\mathrm{Fe}_{3} \mathrm{O}_{4} @ \mathrm{MnO}_{2}$ Hollow Spheres. J. Mol. Liq., 223, 534-540. https://doi.org/10.1016/j.molliq.2016.07.136

[33] Yang, C., Niu, D., Zhong, Y., Li, L., Lv, H. and Liu, Y. (2018) Adsorption of Uranium by Hydrous Manganese Dioxide from Aqueous Solution. J. Radioanal. Nucl. Chem., 315, 533-542. https://doi.org/10.1007/s10967-018-5705-8

[34] Wang, X., Zhu, G. and Guo, F. (2013) Removal of Uranium (VI) Ion from Aqueous Solution by SBA-15. Ann. Nucl. Energy, 56, 151-157.

https://doi.org/10.1016/j.anucene.2013.01.041

[35] Yang, S., Qian, J., Kuang, L. and Hua, D. (2017) Ion-Imprinted Mesoporous Silica for Selective Removal of Uranium from Highly Acidic and Radioactive Effluent. ACS Appl. Mater. Interfaces, 9, 29337-29344. https://doi.org/10.1021/acsami.7b09419

[36] Sun, Y., Wu, Z.-Y., Wang, X., Ding, C., Cheng, W., Yu, S.-H. and Wang, X. (2016) Macroscopic and Microscopic Investigation of U (VI) and Eu (III) Adsorption on Carbonaceous Nanofibers. Environ. Sci. Technol., 50, 4459-4467. https://doi.org/10.1021/acs.est.6b00058

[37] Monier, M. and Elsayed, N.H. (2014) Selective Extraction of Uranyl Ions Using Ion-Imprinted Chelating Microspheres. J. Colloid Interface Sci., 423, 113-122. https://doi.org/10.1016/j.jcis.2014.02.015

[38] Zhang, J., Zhang, H., Liu, Q., Song, D., Li, R., Liu, P. and Wang, J. (2019) Diaminomaleonitrile Functionalized Double-Shelled Hollow MIL-101 (Cr) for Selective Removal of Uranium from Simulated Seawater. Chem. Eng. J., 368, 951-958. https://doi.org/10.1016/j.cej.2019.02.096

[39] Hamza, M.F., Aly, M.M., Abdel-Rahman, A.A.-H., Ramadan, S., Raslan, H., Wang, S., Vincent, T. and Guibal, E. (2017) Functionalization of Magnetic Chitosan Particles for the Sorption of U (VI), Cu (II) and Zn (II): Hydrazide Derivative of Glycine-Grafted Chitosan. Materials, 10, 539. https://doi.org/10.3390/ma10050539

[40] Christou, C., Philippou, K., Krasia-Christoforou, T. and Pashalidis, I. (2019) Uranium Adsorption by Polyvinylpyrrolidone/Chitosan Blended Nanofibers. Carbohydr. Polym., 219, 298-305. https://doi.org/10.1016/j.carbpol.2019.05.041

[41] Saleh, T.A., Tuzen, M. and Sar1, A. (2017) Polyethylenimine Modified Activated Carbon as Novel Magnetic Adsorbent for the Removal of Uranium from Aqueous Solution. Chem. Eng. Res. Des., 117, 218-227.

https://doi.org/10.1016/j.cherd.2016.10.030

[42] Li, M., Liu, H., Chen, T., Dong, C. and Sun, Y. (2019) Synthesis of Magnetic Biochar Composites for Enhanced Uranium (VI) Adsorption. Sci. Total Environ., 651, 1020-1028. https://doi.org/10.1016/j.scitotenv.2018.09.259

[43] Abdi, S., Nasiri, M., Mesbahi, A. and Khani, M.H. (2017) Investigation of Uranium (VI) Adsorption by Polypyrrole. J. Hazard. Mater., 332, 132-139. https://doi.org/10.1016/j.jhazmat.2017.01.013

[44] Anirudhan, T.S., Lekshmi, G.S. and Shainy, F. (2019) Synthesis and Characterization of Amidoxime Modified Chitosan/Bentonite Composite for the Adsorptive Removal and Recovery of Uranium from Seawater. J. Colloid Interface Sci., 534, 248-261. https://doi.org/10.1016/j.jcis.2018.09.009

[45] Xie, L., Zhong, Y., Xiang, R., Fu, G., Xu, Y., Cheng, Y., Liu, Z., Wen, T., Zhao, Y. 
and Liu, X. (2017) Sono-Assisted Preparation of Fe (II)-Al (III) Layered Double Hydroxides and Their Application for Removing Uranium (VI). Chem. Eng. J., 328, 574-584. https://doi.org/10.1016/j.cej.2017.07.051 